\title{
Molecular identification of coprophilous microfungi from Banyumas District, Central Java, Indonesia
}

\author{
ARIS MUMPUNI", ADI AMURWANTO, DANIEL JOKO WAHYONO \\ Faculty of Biology, Universitas Jenderal Soedirman. J1. Dr. Soeparno 63, Purwokerto Utara, Banyumas 53122, Central Java, Indonesia \\ Tel.: +62-281638794, Fax.: +62-281-631700, `email: aris.mumpuni@unsoed.ac.id, arismumpuni@gmail.com
}

Manuscript received: 30 November 2020. Revision accepted: 28 February 2021.

\begin{abstract}
Mumpuni A, Amurwanto A, Wahyono DJ. 2021. Molecular identification of coprophilous microfungi from Banyumas District, Central Java, Indonesia. Biodiversitas 22: 1550-1557. Coprophilous microfungi are a group of fungi that are ecologically interesting in relation to herbivores. These fungi play a predominant role in the decomposition of organic matter, in which the organic matter passes through a series of events involving mechanical degradation, as well as physical and biological processes. The role of coprophilous fungi as the main decomposers of the lignocellulosic material of herbivorous animal waste, which is widespread in nature, is very important. Previous research on the inventory and identification of coprophilous fungi in the Banyumas district has been limited to macroscopic genera, so the results have not been able to provide a comprehensive picture of the presence of coprophilous fungi in the region. Identification of the types of microscopic coprophilous fungi that live in herbivorous animal waste, such as lignocellulosic material, is necessary to understand the taxonomy of these fungi. This study aimed to investigate and identify microscopic coprophilous fungi obtained in the Banyumas district of Central Java, Indonesia. Based on the purposive random sampling method, the obtained fungi were analyzed using the molecular methods of DNA isolation, gene amplification, DNA sequencing and phylogenetic analysis of fungal cultures. The following species and genera were identified: Ceriporia lacerata, Trichosporon insectorum, Lentinus squarrosulus, Fusarium sp., Aspergillus sp., and Trichosporon sp.
\end{abstract}

Keywords: Coprophilous fungi, inventory, molecular identification

\section{INTRODUCTION}

Coprophilous fungi are saprophytic fungi that live on animal dung. These fungi utilize the feces of various animals, especially herbivores, as their substrates (Melo et al. 2012). These fungi belong to the phyla Zygomycota, Ascomycota, and Basidiomycota (Masunga et al. 2006). According to Krug et al. (2004), most coprophilous fungi inhabit the dung of herbivorous livestock, such as sheep and cattle. According to Sinsabaugh et al. (1981), these fungi spread widely wherever herbivorous animals are present and play a predominant role in the decomposition of organic matter. The organic matter is broken down by a series of events involving physical processes, such as leaching and mechanical degradation, as well as through biological processes, such as degradation by microbes involving several exoenzymes.

Four genera of macroscopic coprophilous fungi, Coprinopsis, Panaeolus, Mycena, and Stropharia, were found in the coastal tourism area of Parangtritis, Yogyakarta, Indonesia (Mumpuni and Wahyono 2016). Furthermore, Mumpuni et al. (2020) reported 12 genera of macroscopic coprophilous fungi, Panaeolus, Coprinopsis, Stropharia, Tricholoma, Lycoperdon, Ascobolus, Rhodocybe, Conocybe, Bolbitius, Leucocoprinus, Mycena, and Hypholoma, in the former Banyumas residence (regencies of Banjarnegara, Purbalingga, Banyumas and Cilacap). The studies on coprophilous fungi from the previous studies were limited to the macroscopic fungi found at the time of sampling. To obtain more comprehensive results, broader research involving the isolation of microscopic coprophilous fungi from herbivorous animal waste is needed.

Zuber et al. (2011) reported that the standard method for identifying fungal species is morphological analysis, which consists of macroscopic and microscopic observations. Macroscopic analysis consists of the determination of the color, size, and structural characteristics of the fruiting body. Further analysis of microscopic characteristics is performed mainly by comparison of spore appearance. An alternative to morphological analysis is the identification of fungal species based on phylogenetic studies. Among such studies, the DNA forensic method (Hebert et al. 2004) has been applied to evaluate polymorphisms in two noncoding polymorphic internal transcriber spacers (ITS1 and ITS2). The ITS regions are extremely useful for species identification because of their long, sequential polymorphisms. DNA sequence analysis of ITS1 and ITS2 has been successfully used for taxonomic studies of fungi (Nilson et al. 2008), and these regions are common markers used for the identification of fungal species (Lee et al. 2000). Studies have proven that the ITS region provides excellent results in molecular systematics down to the species level, as well as in the determination of geographical variations among species. Studies have evaluated the effectiveness of ITS polymorphism analysis for forensic purposes in the differentiation of psychotropic 
fungi of the genera Panaeolus and Psilocybe, based on the lengths of polymorphisms identified in ITS1/2 amplification products.

Use of molecular tools to complement morphological characteristics is a promising approach for rapid identification of species for reliable evaluation of biological diversity. These markers have been effectively and successfully used for the identification of fungal species since the 1990s (White et al. 1991; Bruns et al. 1991). However, strategies based on sequencing of standardized genomic fragments (DNA barcoding) were recognized much later (Hollingsworth 2007). The primary difference between molecular identification tools and the "DNA barcode" approach is that the latter involves the use of a standard DNA region that is specific for a taxonomic group. Badotti et al. (2017) suggested that one advantage of using the ITS region as a standard marker is that most fungal species have been identified based on this genomic region.

To reveal the taxonomic identity and bioprospection of coprophilous fungi, we investigated and identified microscopic coprophilous fungi obtained in the Banyumas district in Central Java, Indonesia.

\section{MATERIALS AND METHODS}

\section{Study area}

The survey of study area for the collection of the coprophilous fungi from cow dung was carried out in
Baturraden, Kedungbanteng, and Cilongok sub-districts (ranged between $7^{\circ} 03^{\prime}-7^{\circ} 38^{\prime}$ South Latitude and $109^{\circ} 10^{\prime}$ - $109^{\circ} 25^{\prime}$ East Longitude) in the Banyumas District in Central Java, Indonesia.

\section{Sampling, isolation and purification of coprophilous fungi}

The dung samples were obtained from a maximum depth of $10 \mathrm{~cm}$ below the surface of a 1-month-old dung pile in a landfill with the help of a pry tool. The coprophilous fungi were isolated via a $10^{-3}$ to $10^{-5}$ dilution series. A drop of the diluted extract was placed on soil extract agar (glucose 1g; dipotassium phosphate $0.5 \mathrm{~g}$; soil extract $17.75 \mathrm{~g}$; agar $15 \mathrm{~g}$ with final $\mathrm{pH}$ at $25^{\circ} \mathrm{C} 6.8 \pm 0.2$ ) containing chloramphenicol and then incubated at room temperature for 3-7 days. The fungi grow on this medium were then purified by serial culture on potato dextrose agar until pure cultures were obtained. Subsequently, the purified fungi were inoculated into malt extract broth and incubated at room temperature for 15 days until the mycelia filled the Erlenmeyer flask. Mycelia were harvested via filtration and washed twice with distilled water. The wet mycelia were then either used immediately for DNA isolation or freeze-dried and stored at $-20^{\circ} \mathrm{C}$ for later DNA isolation.

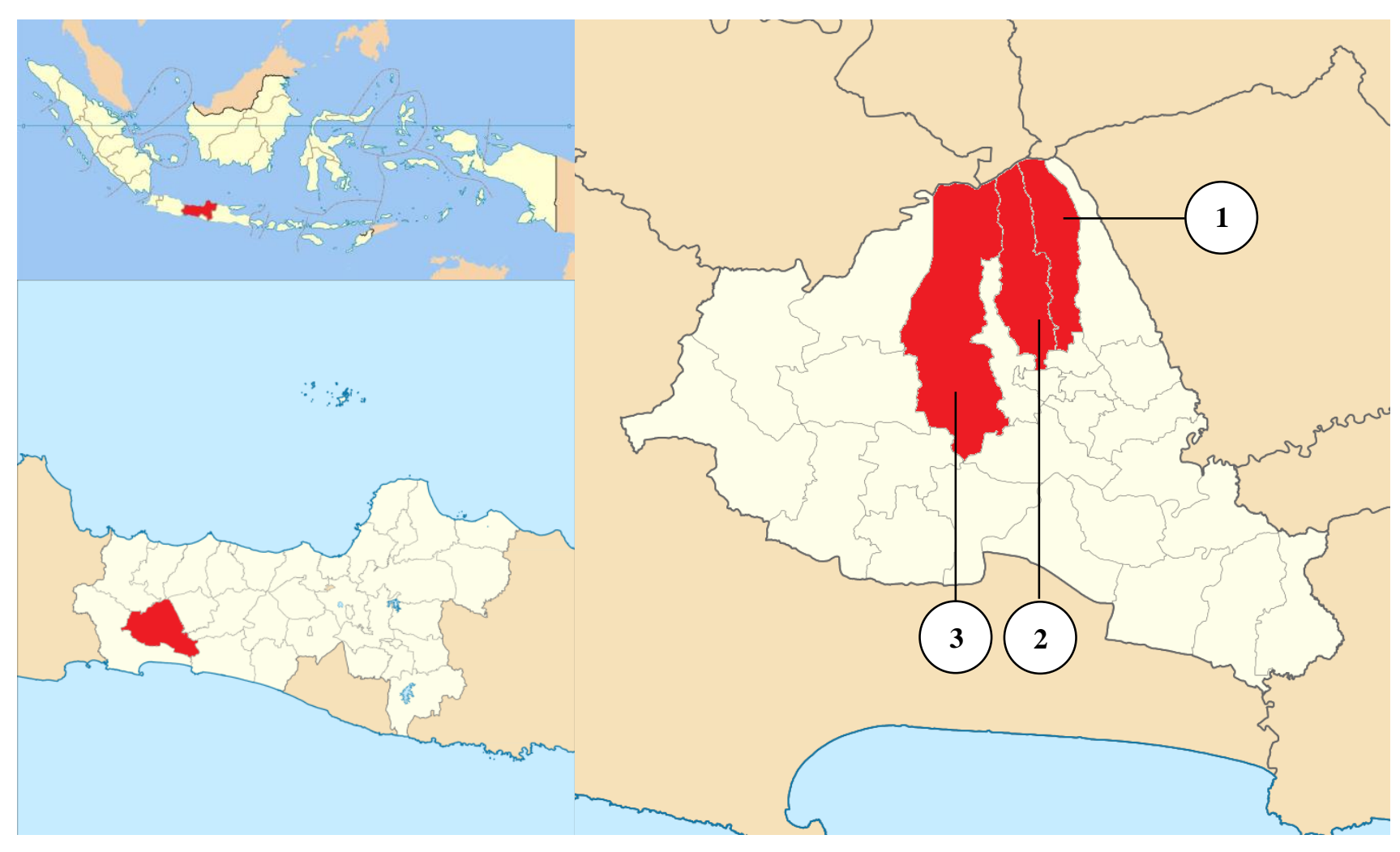

Figure 1. Map showing sampling sites in Banyumas District, Central Java, Indonesia. 1. Baturraden, 2. Kedungbanteng and 3. Cilongok 


\section{Molecular identification of coprophilous fungi}

Isolation of DNA from the purified coprophilous fungal isolates was performed using the Presto ${ }^{\mathrm{TM}}$ Mini gDNA kit for yeast (Geneaid) until $100 \mu \mathrm{L}$ of the DNA solution was obtained. DNA solutions were used immediately for PCR analysis or stored at $-80^{\circ} \mathrm{C}$ for later analysis. The ITS locus was amplified using the primer sequences of ITS1 (5'-TCCGTAGGTGAACCTGCGG-3') and ITS4 (5'-TCCTCCGCTTATTGATGC-3'). The PCR mixture (25 $\mu \mathrm{L}$ total volume) consisted of $1 \mu \mathrm{L}$ genomic DNA template, $12.5 \mu \mathrm{L} 2 \times$ MyTaq Red Mix (Bioline), $1 \mu \mathrm{L}$ each primer $(20 \mu \mathrm{M} / \mu \mathrm{L})$, and $9.5 \mu \mathrm{L}$ double-distilled $\mathrm{H}_{2} \mathrm{O}$. Amplification was carried out for 35 cycles on the Applied Biosystems 96-Well GeneAmp 9700 thermal cycler using the following conditions: pre-denaturation at $95^{\circ} \mathrm{C}$ for 3 min, denaturation at $95^{\circ} \mathrm{C}$ for $10 \mathrm{~s}$, annealing at $52^{\circ} \mathrm{C}$ for $30 \mathrm{~s}$, and extension at $72^{\circ} \mathrm{C}$ for $45 \mathrm{~s}$. The DNA amplicon was visualized using 1-2\% agarose gel electrophoresis. The PCR products were purified using the Zymoclean ${ }^{\mathrm{TM}}$ Gel DNA Recovery Kit (Zymo Research). The purified PCR products were then outsourced to PT Genetika Science Indonesia for DNA sequencing. The sequence data were submitted to GenBank (http://www.ncbi.nlm.nih.gov/) for data analysis.

\section{Data analysis}

Electropherograms were edited manually, contigs were merged, and multiple alignments were made for all data sequences using Genetool software (Biotools Inc). The neighbor-joining distance algorithm with the Kimura2 parameter model using PAUP (v.4.0b10) (Swofford 2000) was used for phylogenetic analysis. Heuristic analysis using parsimony was also performed.

\section{RESULTS AND DISCUSSION}

\section{Results}

Total of 16 samples of coprophilous fungal isolates exhibiting different somatic phase characteristics was obtained (Fig. 1). The fungal isolates were purified and subjected to DNA extraction.

Table 1. shows the genomic DNA quantification results for DNA extracts from the coprophilous fungal isolates. The purity of each DNA extract was determined according to the 260/280 nm absorbance ratio. Samples KB2-1, LP11, and LP4-1 are free of RNA and protein contamination as they showed absorbance ratio of 1.8; samples KN1-1, KN1-2, KN2-1, KN3-1, KN3-2, KN4-1, KB1-1, BJ1-1, BJ3-1, LP1-2, LP1- 3, and LP1-5 with the absorbance ratio greater than 1.8 indicated possible RNA contamination; while, a ratio less than 1.8 (viz., KN3-3) indicated possible protein contamination (Sambrook and Russel 2001). Several isolates (viz., KN1-1, KN3-1, KN3-3, and LP1-2) had concentrations substantially less than $20 \mathrm{ng} / \mu \mathrm{L}$, which
DOI: $10.13057 /$ biodiv/d220361

was not optimal for spectrophotometric analysis; however, in general, the DNA of these isolates exhibited reasonably good purity.

We also measured the 260/230 absorbance ratio. According to Boyer (2005), a ratio ranging from 2.0 to 2.2 indicates a lack of polysaccharide contamination. The relatively low 260/230 ratios observed in our samples suggested possible contamination with carbohydrates, organic matter, or other chemicals.

Figure 2 shows DNA amplification of the ITS gene locus from coprophilous fungal samples. Of the 16 samples of coprophilic fungi isolated from cow dung, only 9 (KN11, KN1-2, KN3-1, KN3-2, KN3-3, KN4-1, KB1-1, BJ3-1, and LP1-3) showed optimal DNA amplification, as evidenced by a specific, single, thick DNA band, which indicates optimal quantity and purity of the extracted genomic DNA (Sambrook and Russel 2001). According to Agrawal (2008), the purity of the DNA sample can affect the PCR results. Consequently, DNA sequencing was performed in these nine samples (Table 2).

The DNA sequencing results of the nine selected samples are shown in Table 2. All but one (KB1-1) of the samples exhibited good purity. According to Bruce et al. (2002), factors affecting DNA sequencing results include denaturation, annealing and extension temperatures, and the degree of DNA molecule separation during the purification and precipitation steps.

The results of nucleotide BLAST searches against the NCBI database are shown in Table 3. The samples KN1-1, KN1-2. KN3-1, KN3-2, KN3-3, BJ3-1, and LP1-3 exhibited consistent BLAST hits from one or two specific species; any differences were in the homotypic synonym, taxon synonym, or obligate synonym of the current name of the species.

Table 1. Fungal genomic DNA quantification

\begin{tabular}{llllr}
\hline Sample & Conc. $(\mathbf{n g} / \boldsymbol{\mu L})$ & A260/280 & A260/230 & Volume $(\boldsymbol{\mu L})$ \\
\hline KN1-1 & 14.2 & 1.98 & 0.30 & 40 \\
KN1-2 & 31.6 & 1.98 & 0.14 & 40 \\
KN2-1 & 29.0 & 1.93 & 0.41 & 40 \\
KN3-1 & 9.3 & 2.02 & 0.14 & 40 \\
KN3-2 & 22.3 & 1.90 & 0.17 & 40 \\
KN3-3 & 9.6 & 1.65 & 0.39 & 40 \\
KN4-1 & 22.3 & 1.90 & 0.17 & 40 \\
KB1-1 & 18.0 & 2.01 & 0.19 & 40 \\
KB2-1 & 96.9 & 1.89 & 0.82 & 40 \\
BJ1-1 & 18.0 & 1.94 & 0.12 & 40 \\
BJ3-1 & 26.7 & 1.94 & 0.11 & 40 \\
LP1-1 & 23.1 & 1.89 & 0.04 & 40 \\
LP1-2 & 11.7 & 1.98 & 0.11 & 40 \\
LP1-3 & 24.5 & 1.92 & 0.28 & 40 \\
LP1-4 & 21.1 & 1.86 & 0.27 & 40 \\
LP1-6 & 55.5 & 1.93 & 0.58 & 40 \\
\hline
\end{tabular}



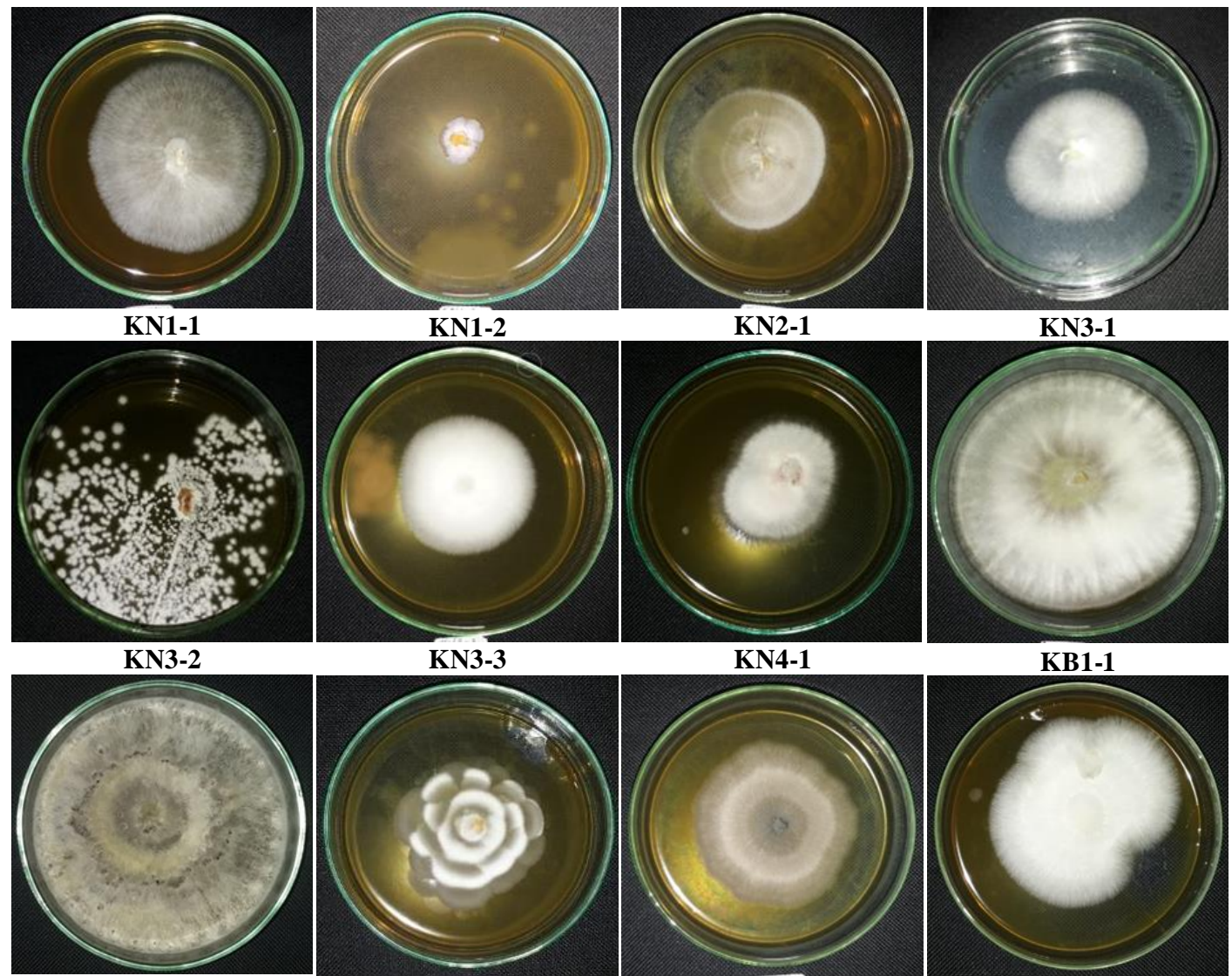

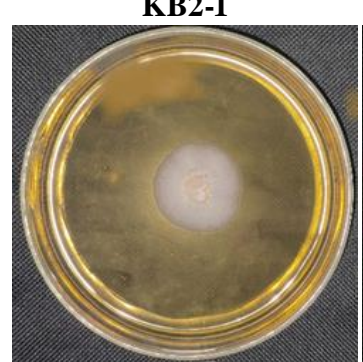

LP1-2

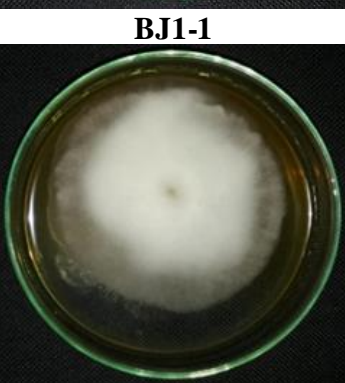

LP1-3

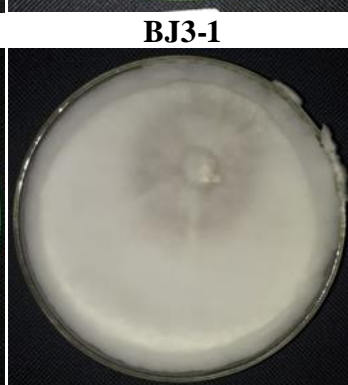

LP1-4
KB1-1
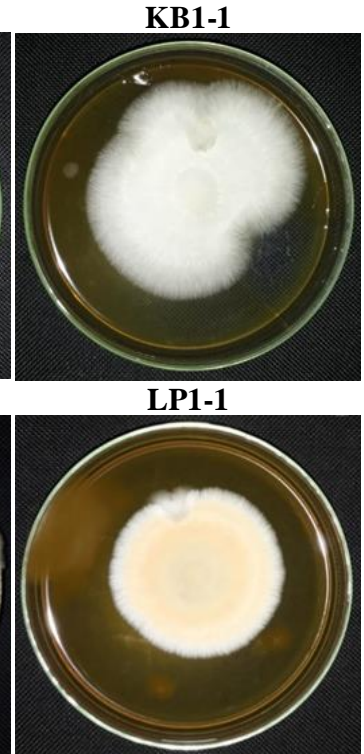

LP1-5

Figure 1. Five-day-old cultures of coprophilous fungal isolates from Banyumas District, Central Java, Indonesia. Isolates KN1-1, KN12, KN2-1, KN3-1, KN3-2, KN3-3, and KN4-1 were obtained from Baturraden sub-district; isolates KB1-1, KB2-1, BJ1-1, and BJ3-1 were obtained from Kedungbanteng sub-district; isolates LP1-1, LP1-2, LP1-3, LP1-4, and LP1-5 were obtained from Cilongok subdistrict.
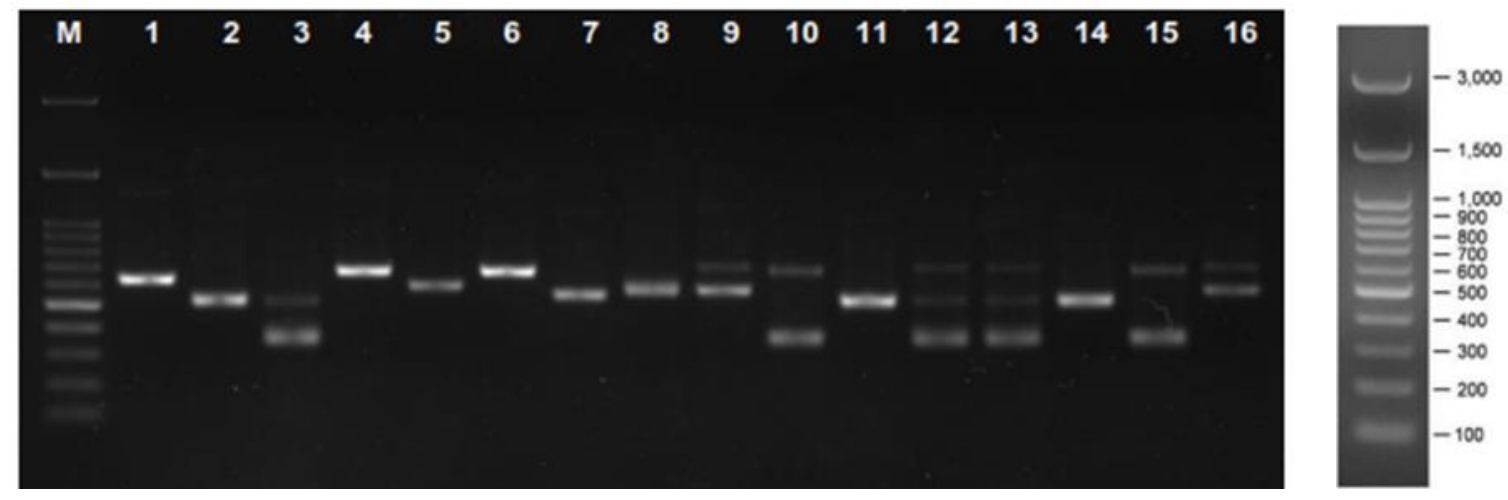

Figure 2. Amplified ITS gene loci from coprophilous fungal samples. Well "M", DNA ladder 100 bp; wells 1-16, coprophilous fungal DNA samples 
Table 2. DNA sequence assemblies of PCR-amplified noncoding polymorphic internal transcriber spacers from coprophilous fungal samples

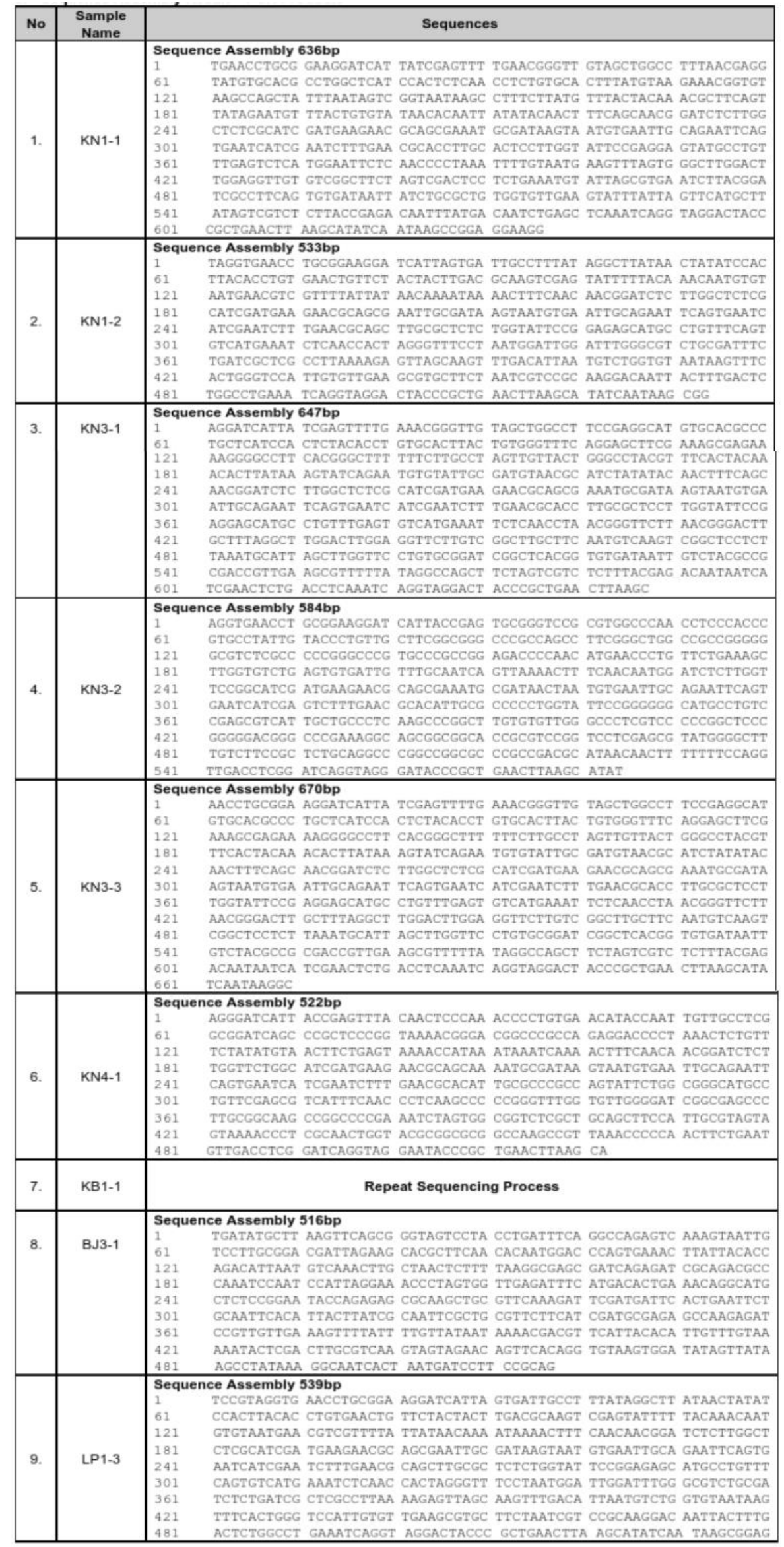


Table 3. Results of nucleotide BLAST searches against the NCBI database

\begin{tabular}{|c|c|c|c|c|c|c|}
\hline \multirow[b]{2}{*}{ Sample } & \multicolumn{6}{|c|}{ Result links } \\
\hline & Description & $\begin{array}{l}\text { Max } \\
\text { score }\end{array}$ & $\begin{array}{l}\text { Total } \\
\text { score }\end{array}$ & $\begin{array}{l}\text { Query } \\
\text { cover }\end{array}$ & $\begin{array}{l}\mathbf{E} \\
\text { value }\end{array}$ & Per ident. \\
\hline \multirow[t]{10}{*}{ KN1-1 } & Emmia lacerata isolate A01 & 1136 & 1136 & $99 \%$ & 0.0 & $99.84 \%$ \\
\hline & Ceriporia lecerata isolate A1S5-D23 & 1135 & 1135 & $100 \%$ & 0.0 & $99.69 \%$ \\
\hline & Ceriporia lacerata isolate BPEF81 & 1123 & 1123 & $99 \%$ & 0.0 & $99.52 \%$ \\
\hline & Ceriporia lacerata isolate WS1JB14 & 1121 & 1121 & $97 \%$ & 0.0 & $100.00 \%$ \\
\hline & Ceriporia lacerata isolate $\mathrm{X} 12$ & 1118 & 1118 & $99 \%$ & 0.0 & $99.21 \%$ \\
\hline & Emmia lacerata MYA 12S07 & 1116 & 1116 & $99 \%$ & 0.0 & $99.21 \%$ \\
\hline & Emmia sp. strain Cef 13 & 1116 & 1116 & $99 \%$ & 0.0 & $99.21 \%$ \\
\hline & Ceriporia lacerata isolate CIFE 29 & 1116 & 1116 & $98 \%$ & 0.0 & $99.52 \%$ \\
\hline & Basidiomycota sp. SYBC-L17 & 1116 & 1116 & $99 \%$ & 0.0 & $99.21 \%$ \\
\hline & Ceriporia lacerata genes for $18 \mathrm{~S}$ & 1116 & 1116 & $99 \%$ & 0.0 & $99.21 \%$ \\
\hline
\end{tabular}

http://www.ncbi.nlm.nih.gov/nuccore/MH734799.1,KJ780757.1,KF151851.1,KT844687.1,KF850375.1,LC431580.1, MK775821.1,KM388611.1,HQ891300.1,LC312413.1

\begin{tabular}{|c|c|c|c|c|c|c|}
\hline \multirow[t]{10}{*}{ KN1-2 } & Trichosporon asahii strain CU12015 6 & 962 & 962 & $100 \%$ & 0.0 & $100 \%$ \\
\hline & Trichosporon asahii isolate M15 & 962 & 962 & $100 \%$ & 0.0 & $100 \%$ \\
\hline & Trichosporon sp. isolate EE (19)-CHc & 962 & 962 & $100 \%$ & 0.0 & $100 \%$ \\
\hline & Trichosporon asahii isolate E22922 & 962 & 962 & $100 \%$ & 0.0 & $100 \%$ \\
\hline & Trichosporon asahii strain DMic 165073 & 962 & 962 & $100 \%$ & 0.0 & $100 \%$ \\
\hline & Trichosporon asahii culture CBS 2497 & 962 & 962 & $100 \%$ & 0.0 & $100 \%$ \\
\hline & Trichosporon asahii strain V9 & 962 & 962 & $100 \%$ & 0.0 & $100 \%$ \\
\hline & Trichosporon asahii strain 18S & 962 & 962 & $100 \%$ & 0.0 & $100 \%$ \\
\hline & Trichosporon asahii strain APMSU6 & 962 & 962 & $100 \%$ & 0.0 & $100 \%$ \\
\hline & Trichosporon asahii strain YCH116 & 962 & 962 & $100 \%$ & 0.0 & $100 \%$ \\
\hline
\end{tabular}

http://www.ncbi.nlm.nih.gov/nuccore/MT482659.1,MT136544.1,MK267768.1,MG241533.1,KY105711.1,KT900123. 1,KT900118.1,KT282395.1,KM982986.1

\begin{tabular}{|c|c|c|c|c|c|c|}
\hline \multirow[t]{10}{*}{ KN3-1 } & Lentinus squarrosulus isolate TAM1004 & 1168 & 1168 & $100 \%$ & 0.0 & $100 \%$ \\
\hline & Lentinus squarrosulus voucher WARRIPt & 1168 & 1168 & $100 \%$ & 0.0 & $100 \%$ \\
\hline & Lentinus squarrosulus voucher WARRI34 & 1168 & 1168 & $100 \%$ & 0.0 & $100 \%$ \\
\hline & Lentinus squarrosulus voucher UNIP13 & 1168 & 1168 & $100 \%$ & 0.0 & $100 \%$ \\
\hline & Lentinus squarrosulus voucher Odi26 & 1168 & 1168 & $100 \%$ & 0.0 & $100 \%$ \\
\hline & Lentinus squarrosulus voucher IBD43 & 1168 & 1168 & $100 \%$ & 0.0 & $100 \%$ \\
\hline & Lentinus sp. BAB5060 & 1168 & 1168 & $100 \%$ & 0.0 & $100 \%$ \\
\hline & Lentinus squarrosulus voucher BORH0009 & 1162 & 1162 & $99 \%$ & 0.0 & $100 \%$ \\
\hline & Lentinus squarrosulus small subunit ribosomal & 1159 & 1159 & $100 \%$ & 0.0 & $99.85 \%$ \\
\hline & Lentinus squarrosulus strain WCR1201 & 1155 & 1155 & $100 \%$ & 0.0 & 99.69 \\
\hline
\end{tabular}

http://www.ncbi.nlm.nih.gov/nuccore/MH172168.1,KT273380.1,KT273379.1,KT273370.1,KT273364.1,KR155105.1 ,MH053154.1,KT956127.1

\begin{tabular}{|c|c|c|c|c|c|c|}
\hline \multirow[t]{10}{*}{ KN3-2 } & Aspergillus allahabadii strain CGMC 303920 & 1054 & 1054 & $100 \%$ & 0.0 & $100 \%$ \\
\hline & Aspergillus allahabadii strain CGMC 302584 & 1054 & 1054 & $100 \%$ & 0.0 & $100 \%$ \\
\hline & Aspergillus allahabadii genes for 18S rRNA & 1054 & 1054 & $100 \%$ & 0.0 & $100 \%$ \\
\hline & Aspergillus candidus isolate CY104 & 1054 & 1054 & $100 \%$ & 0.0 & $100 \%$ \\
\hline & Aspergillus allahabadii strain CMV004E2 & 1049 & 1049 & $100 \%$ & 0.0 & $99.83 \%$ \\
\hline & Aspergillus allahabadii strain CGMCC 301332 & 1049 & 1049 & $100 \%$ & 0.0 & $99.83 \%$ \\
\hline & Aspergillus niveus strain URM7046 & 1048 & 1048 & $99 \%$ & 0.0 & $99.83 \%$ \\
\hline & Aspergillus niveus strain CBS 132162 & 1045 & 1045 & $100 \%$ & 0.0 & $99.66 \%$ \\
\hline & Aspergillus allahabadii strain NN046949 & 1043 & 1043 & $98 \%$ & 0.0 & $100 \%$ \\
\hline & Aspergillus niveus strain NN043511 & 1043 & 1043 & $98 \%$ & 0.0 & $100 \%$ \\
\hline
\end{tabular}

http://www.ncbi.nlm.nih.gov/nuccore/MH292843.1,MH292842.1,LC152416.1,HQ607958.1,MK450628.1,MH292844 .1,KM613137.1,MH865978.1,KX443215.1,KX443211.1

$\begin{array}{llllll}\text { Lentinus sp. BAB-5060 } & 1205 & 1205 & 99 \% & 0.0 & 100 \% \\ \text { Lentinus squarrosulus voucher WARRIPt } & 1196 & 1196 & 98 \% & 0.0 & 100 \% \\ \text { Lentinus squarrosulus voucher Odi26 } & 1196 & 1196 & 98 \% & 0.0 & 100 \% \\ \text { Lentinus squarrosulus strain WCR1201 } & 1193 & 1193 & 99 \% & 0.0 & 99.70 \% \\ \text { Lentinus squarrosulus voucher UNIP13 } & 1191 & 1191 & 98 \% & 0.0 & 100 \% \\ \text { Lentinus squarrosulus voucher WARRI34 } & 1189 & 1189 & 98 \% & 0.0 & 100 \% \\ \text { Lentinus squarrosulus IBD43 } & 1189 & 1189 & 98 \% & 0.0 & 100 \% \\ \text { Lentinus sp. S5 } & 1188 & 1188 & 99 \% & 0.0 & 99.55 \% \\ \text { Lentinus squarrosulus small subunit } & 1185 & 1185 & 98 \% & 0.0 & 99.85 \% \\ \text { Lentinus squarrosulus voucher BORH0009 } & 1180 & 1180 & 97 \% & 0.0 & 100 \%\end{array}$

http://www.ncbi.nlm.nih.gov/nuccore/KR155105.1,KT273380.1,KT273370.1,KT956127.1,KT273373.1,KT273379.1, KT273364.1,JN253598.1,MH053154.1,KP283484.1 
commonly found growing in the wild on decaying tree trunks during the rainy season. Similar to other macrofungal species, this fungus can grow in a wide variety of substrates and habitats. Many Lentinus species have been reported to grow in nature on special substrates as well as on pasteurized substrates (Morais et al. 2000; Philippousis et al. 2001). Hu et al. (2013) discovered Aspergillus allahabadii growing on the rock faces of Angkor Thom Cambodia temples. Microbial biofilms on the surface of the temple stone destroy the integrity of the substrate material and is a biodeteriogen responsible for the destruction of the temple stones over time.

To conclude, we have uncovered the existence of coprophilous microscopic fungi occurring in Banyumas District in Central Java, Indonesia identified as Ceriporia lacerata, Trichosporon insectorum, and Lentinus squarrosulus, Fusarium sp., Aspergillus sp., and Trichosporon sp. Further investigations are needed to identify the fungi morphologically and to evaluate the utility of these fungi for various human interests.

\section{ACKNOWLEDGEMENTS}

The author thanks Rector and Head of LPPM of Universitas Jenderal Soedirman, Banyumas, Indonesia for providing the permission and funding to undertake this research through the research scheme of Improvement of Competence 2020 .

\section{REFERENCES}

Agrawal S. 2008. Techniques in Molecular Biology. International Book Distributing Co., Lucknow.

Al-Ansari MSA. 2018. Etiology of maize root rot in Oman: causal agents and effects of a compost-based organic growing system. [Dissertation]. Faculty of Organic Agricultural Sciences of the University of Kassel, Germany.

Badotti F, de Oliveira FS, Garcia CF, Vaz ABM, Fonseca PLC, Nahum LA, Oliveira G, Góes-Neto A. 2017. Effectiveness of ITS and subregions as DNA barcode markers for the identification of Basidiomycota (Fungi). BMC Microbiol 17 (42): 1-12. DOI: 10.1186/s12866-017-0958-x.

Boyer R. 2005. Modern Experimental Biochemistry. $3^{\text {rd }}$ ed. Pearson Education, Inc., India

Bruce A, Johnson A, Lewis J, Raff M, Roberts K, Walter P. 2002 Molecular Biology of the Cell. 4th ed. Garland Science, New York.

Bruns TD, White TJ, Taylor JW. 1991. Fungal molecular systematics. Ann Rev Ecol Syst 22: 525-564. DOI 10.1146/annurev.es.22.110191.002521.

Cen YK, Lin JG, Wang YL, Wang JY, Liu ZQ, Zheng YG. 2020. The gibberellin producer Fusarium fujikuroi: methods and technologies in the current toolkit. Front Bioeng Biotechnol 8: 232. DOI: 10.3389/fbioe. 2020.00232 .

Hebert PDN, Stoeckle MY, Zemlak TS, Francis CM. 2004. Identification of birds through DNA barcodes. PLoS Biol 2 (10): 1657-1663. DOI: 10.1371/journal.pbio.0020312.

Hollingsworth PM. 2007. DNA barcoding: potential users. Genome Soc Pol 3: 44-47.

Hu H, Ding S, Katayama Y, Kusumic A, Li SX, de Vries RP, Wang J, Yu XZ, Gu JD. 2013. Occurrence of Aspergillus allahabadii on sandstone at Bayon temple, Angkor Thom, Cambodia. Int Biodeterior Biodegrad 76: 112-117. DOI: 10.1016/j.ibiod.2012.06.022.
Krug JC, Benny GL, Keller HW. 2004. Coprophilous fungi. In: Mueller GM, Bills GF, Foster MS (eds) Biodiversity of Fungi. Elsevier, Amsterdam.

Lee JS, Ko KS, Jung HK. 2000. Phylogenetic analysis of Xylaria based on nuclear ribosomal ITS1-5.8S-ITS2 sequences. FEMS Microbiol Lett 187: 89-93. DOI: 10.1111/j.1574-6968.2000.tb09142.x.

Lorliam W, Akaracharanya A, Suzuki M, Ohkuma M, Tanasupawati S. 2013. Diversity and fermentation products of xylose-utilizing yeasts isolated from buffalo feces in Thailand. Microbes Environ 28 (3): 354-360.

Makhuvele R, Ncube I, van Rensburg ELJ, La Grange DC. 2017. Isolation of fungi from dung of wild herbivores for application in bioethanol production. Braz J Microbiol 48: 646-655. DOI: DOI: 10.1016/j.bjm.2016.11.013.

Masunga GS, Andresen O, Taylor JE, Dhillion SS. 2006. Elephant dung decomposition and coprophilous fungi in two habitats of semi-arid Botswana. Mycol Res 110 (10): 1214-1226. DOI: 10.1016/j.mycres.2006.07.004.

Melo RFR, Miller AN, Santiago ALCMA, Maia LC. 2014. The genera Ascobolus and Saccobolus (Ascobolaceae, Pezizales) in Brazil. Mycosphere 5 (6): 790-804.

Melsasail L, Warouw VRC, Kamagi YEB. 2019. Analisis kandungan unsur hara pada kotoran sapi di daerah dataran tinggi dan dataran rendah. Cocos 2 (6):-. [Indonesian]

Morais MH, Ramos AC, Matou N, Santous M, Oliveira EJ. 2000. Note: production of shitake mushroom (Lentinus edodes) on lignocellulosic residues. Food Sci Technol Intl 6: 123-128. DOI: 10.1177/108201320000600206

Mumpuni A, Ekowati N, Wahyono DJ. 2020. The existence of coprophilous macrofungi in Banyumas Central Java. Biodiversitas 21: 282-289. DOI: $10.13057 /$ biodiv/d210135.

Mumpuni A, Wahyono DJ. 2016. Inventarisasi dan identifikasi secara morfologis jamur koprofil di Kawasan Wisata Pantai Parangtritis Yogyakarta. Makalah Seminar Nasional Biologi V UNNES Hilirisasi Hasil Penelitian Biologi dan pendidikan BiologiMelalui Akselerasi Inovasi Berwawawasan Konservasi. Universitas Negeri Semarang, Semarang, Central Java, 29 Oktober 2016. [Indonesian]

Nilson RH, Kristiansson E, Ryberg M. 2008. Intraspecific ITS variability in the kingdom fungi as expressed in the international sequence databases and its implications for molecular species identification. Evol Bioinform 4: 193-201. DOI: 10.4137/EBO.S653.

Obire O, Anyanwu EC, Okigbo RN. 2008. Saprophytic and crude oildegrading fungi from cow dung and poultry droppings as bioremediating agents. J Agric Technol 4 (2): 81-89.

Philippousis A, Zervakis G, Diamantopoulou P. 2001. Bioconversion of agricultural lignocellulosic wastes through cultivation of the edible mushrooms Agrocybe aegerita, Volvariella volvocea and Pleurotus spp. World J Microbiol Biotechnol 17: 191-200. DOI: 10.1023/A:1016685530312.

Sambrook J, Russel DW. 2001. Molecular Cloning: A Laboratory Manual. 3rd ed. Cold Spring Harbor Laboratory Press, New York.

Sinsabaugh RL, Benfield EF, Linkins AE, 1981. Cellulase activity associated with the decomposition of leaf litter in a woodland stream. Oikos 36: 184-190. DOI: 10.2307/3544444.

Stackebrandt E, Goebel BM, 1994. Taxonomic Note: A place for DNADNA reassociation and 16S rRNA sequence analysis in the present species definition in bacteriology. Intl J Syst Evol Microbiol 44: 846849.

Swofford DL. 2000. PAUP*: Phylogenetic analysis using parsimony and other methods, version 4.0b10, Sinauer Associates, Sunderland, MA (Mac version).

White TJ, Bruns T, Lee S, Taylor J. 1990. Amplification and direct sequencing of fungal ribosomal RNA genes for phylogenetics. In: Innis MA, Gelfand DH, Sninsky JJ, White TJ (eds.). PCR Protocols: a Guide to Methods and Applications. Academic Press, London.

Wulandari R, Lotrakul P, Amirta R, Kim SW, Punnapayak H, Prasongsuk S. 2018. First record of Ceriporia inflata and Ceriporia lacerate (Phanerochaetaceae, Basidiomycota) from Indonesian tropical forest. Agric Nat Res 52: 412-418. DOI: 10.1016/j.anres.2018.10.017.

Zuber A, Kowalczyk M, Sekula A, Mleczko P, Kupiec T. 2011. Methods in species identification of hallucinogenic and other poisonous mushrooms in forensic investigation. Probl Forensic Sci 1036: 151161. 